\title{
The Trackless Tram: Is It the Transit and City Shaping Catalyst We Have Been Waiting for?
}

\author{
Peter Newman', Karlson Hargroves ${ }^{1}$, Sebastian Davies-Slate ${ }^{1}$, Daniel Conley², \\ Marie Verschuer $^{3}$, Mike Mouritz ${ }^{1}$, Dorji Yangka ${ }^{1}$ \\ ${ }^{1}$ Curtin University Sustainability Policy Institute (CUSP), Curtin University, Perth, Australia \\ ${ }^{2}$ Entrepreneurship, Commercialisation and Innovation Centre (ECIC) and the School of Civil, Environmental and Mining \\ Engineering, University of Adelaide, Adelaide, Australia \\ ${ }^{3}$ Bodhi Alliance, Perth, Australia \\ Email: p.newman@curtin.edu.au
}

How to cite this paper: Newman, P., Hargroves, K., Davies-Slate, S., Conley, D., Verschuer, M., Mouritz, M. and Yangka, D. (2019) The Trackless Tram: Is It the Transit and City Shaping Catalyst We Have Been Waiting for? Journal of Transportation Technologies, 9, 31-55.

https://doi.org/10.4236/jtts.2019.91003

Received: October 22, 2018

Accepted: December 26, 2018

Published: December 29, 2018

Copyright $\odot 2019$ by authors and Scientific Research Publishing Inc. This work is licensed under the Creative Commons Attribution International License (CC BY 4.0).

http://creativecommons.org/licenses/by/4.0/

\begin{abstract}
Recent innovations in transport technology are now providing mobility that is cheaper, autonomous, electric, and with improved ride quality. While much of the world's attention has been on how this can be applied to cars, there have been rapid adoption of these and other technologies in High Speed Rail and Metro Rail systems that run between and across cities. This paper shows how such innovations have now been applied to create the next generation of urban transit system called a Trackless Tram. Trackless Trams are effectively the same as traditional light rail except they run on rubber tyres avoiding disruption from construction for Light Rail, but they retain the electric propulsion (with batteries) and have high ride quality due to rail-type bogies, stabilization technologies and precision tracking from the autonomous optical guidance systems-with infrastructure costs reduced to as low as one tenth of a Light Rail system. As with Light Rail, a Trackless Tram System provides a rapid transit option that can harness the fixed route assurance necessary to unlock new land value appreciation that can be leveraged to contribute to construction and running costs whilst creating urban regeneration. The paper considers the niche for Trackless Trams in cities along with its potential for city shaping through the creation of urban re-development along corridors. The paper suggests that the adoption of Trackless Tram Systems is likely to grow rapidly as a genuine alternative to car and bus systems, supplementing and extending the niche occupied by Light Rail Transit (LRT). This appears to be feasible in any medium-sized or larger city, especially in emerging and developing economies, and case studies are outlined for Perth and Thimpu to illustrate its potential.
\end{abstract}




\section{Keywords}

Trackless Trams, Trackless Operation, Autonomous, Self-Guiding, City Shaping, Urban Regeneration, Entrepreneur Rail Model, Transit Activated Corridors, Congestion Relief, Job Creation, Sprawl Relief, Environmental Benefits, Social Benefits

\section{Introduction}

\subsection{Overview}

Cities around the world now have a range of new technologies related to transport to choose from, such as electric vehicles and charging infrastructure, driverassist and self-driving vehicles, low-cost sensors, increasing travel data sources, Big Data analytics software, internet-of-things platforms, and even more recently, artificial intelligence, machine learning and distributed ledger technologies. Considering the innovation of autonomous vehicles, Kim [1] suggests that such technologies will have "tremendous implications to the socio-economic environment in the future world". The way that these types of technologies are navigated will have a direct impact on the very functioning of a city, affecting quality of life, accessibility, commuting times, and the level of urban regeneration that can be unlocked by effective and efficient transport networks. The autonomous transport technologies that have come out of motor vehicle research combined with new information and communications technologies (ICT) and smart systems, have not yet found a proper niche in any city. The claims being made based on time savings, safety and environmental grounds include the idea that no other forms of transport will be needed other than autonomous automobiles. Newman and Kenworthy [2] have pointed out that there are already signs that such claims may in fact not live up to this initial hype as visions of cities given over completely to driverless vehicles are unlikely, meaning that the positive benefits of these new technologies may never be fully realised.

On the other hand, the autonomous, electric and stabilization transit technologies developed for High Speed Rail (between cities, over $300 \mathrm{kph}$ ) and Metros or Suburban Rail (within cities, 80 - $150 \mathrm{kph}$ ) have developed the speed, capacity and ride quality that have led to spectacular increases in ridership [3] [4]. These technologies are able to guide trains at high speed to provide passengers with a level of comfort and safety that is unparalleled in the history of mobility. However, the ability to compete with private cars within cities requires mobility systems that can provide transit capacities and speeds similar to or greater than cars (such as light rail or bus rapid transit) so that connection can be achieved along unserved corridors or between corridors. This is usually a missing link in transit systems as light rail transit (LRT) and bus rapid transit (BRT) can be highly disruptive to urban streets and their associated economies in their con- 
struction and can be very expensive compared to a normal bus line. According to Kenworthy and Schiller [5], the resulting emphasis on buses that rarely generate the speed or ride quality that would compete with a car, has meant the cities of the world have been allowing cars to fill this transport niche and enabling them via expensive, publicly-funded urban infrastructure and highways. Newman and Kenworthy [3] show that the results can now be seen in urban congestion, air pollution, a large part of global greenhouse gases, road accidents and urban sprawl as well as many social and economic issues associated with car dependence.

The response in recent years has been the development of autonomous mass transit that can be implemented in car dependent cities to complement and extend the effective catchment of traditional heavy rail or metro-based commuter systems. This is the niche of LRT and BRT, however in order to provide effective solutions for the world's growing cities the technology used must overcome the issues of street disruption and capital costs as well as keeping all the good qualities of an LRT or BRT. This has meant merging innovations from High Speed Rail such as autonomous operation, stabilisation and ride quality, with the best parts of a light rail and a bus, to create a new form of urban transit technology. This paper will examine such a technology, which has been called Autonomous-Rail Rapid Transit (ART) or what we are labelling a Trackless Tram System (TTS).

Both bus and light rail technologies have been developing in recent years. For example, there are now many manufacturers of electrically powered buses, and many cities which are adopting them, to reduce the air pollution, noise and vibration problems associated with conventional diesel buses. A number of guided bus systems have also been installed using a variety of guidance technologies, from mechanical (as in Adelaide's "O-Bahn") through to optical and magnetic systems. Recent light rail vehicles also now feature on-board batteries or super-capacitors enabling wire-free operation (with re-charging at stops), as well as regenerative braking (to save energy), 100\% low floor access (improving customer convenience and accessibility) and improved steering technologies for improved ride quality.

China's CRRC (now the world's largest rolling stock manufacturer) has combined all of these advances into its new "Trackless Tram". This is an articulated, high capacity "Tram" running on rubber tires but with an in-built guidance system offering autonomous optically-guided running and operation. It is battery powered (with recharging at stops or at the end of the trip), avoiding the necessity for overhead wires along the route. It is fully low-floor, but uses improved suspension systems providing high ride quality. It has low axle loads, minimizing the need for expensive guide way infrastructure. It can also operate on regular streets because of its tight turning radius and high hill-climbing ability. Figure 1 shows a popular photo that has been spreading through much social media on the Chinese Trackless Tram System. 


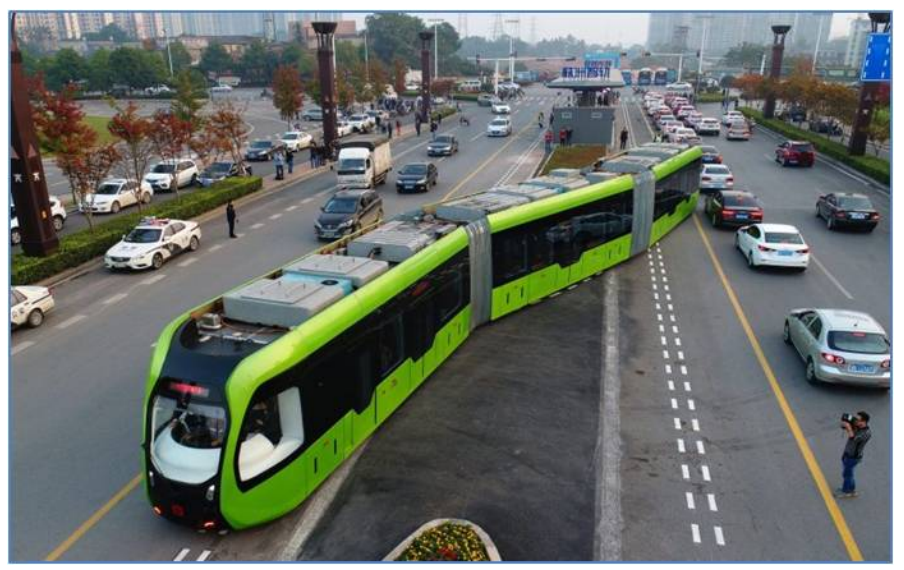

Figure 1. The Trackless Tram System developed by CRRC and demonstrated in Zhuzhou, China. Source: Compliments of CRRC Corporation.

Three of the authors of this paper were able to visit China in August 2018 and ride the Trackless Tram as well as receive detailed explanations about how it works and how the transit system is constructed and operated. The paper is therefore based on this transit technology though it is not excluding other manufacturers such as Alstom, Van Hool, Irizar, and others. The technology was first taken to scale in China in 2016 on a straight $3.6 \mathrm{~km}$ line with 4 stations. Based on findings from the study tour to Zhuzhou, China it is the intention of this paper to not only demonstrate that the Trackless Tram is a superior technology for many corridor connections in urban transit systems but to explore the notion that it is potentially the public transport catalyst that many city planners have been waiting for since the dominance of automobile dependence, as it can unlock urban regeneration. It is the conclusion of this paper that not only is this technology a potential game changer for cities struggling to attract investment in traditional light rail projects, if implemented through an entrepreneurial approach in collaboration with the private sector it stands to unlock significant urban re-development options.

It is important to realise that the Trackless Tram System lends itself to an entrepreneurial approach where secure private sector investment can be attracted to create new development around station precincts, referred to by Newman et al. [6] as the "Entrepreneur Rail Model". This rail development model has a long historical precedent, in both western and Asian cities, and has continued in such places as Japan and Hong Kong. Rail was jointly developed with real estate along both heavy rail lines and tramways/streetcars [7], with the latter filling a similar transport niche to the TTS. This is particularly relevant where cities are growing and hence private investment is likely to be looking for opportunities for urban development that can include a new transit system like a Trackless Tram; this can apply to cities all around the world but especially in developing economies where population growth pressures are high [8]. Such an approach can allow both emerging and developed cities with inadequate legacy transit systems to 
"leap frog" the currently adopted transport technologies and strengthen their economic development whilst assisting in the Sustainable Development Goal of providing an "inclusive, safe, resilient and sustainable city" [9].

\subsection{What Makes a Trackless Tram Different?}

Table 1 sets out the general specifications for a Trackless Tram based on a 3-car set developed by CRRC in China. A Trackless Tram based system blends the best features of bus and train systems, both in the carriage technology and the system configuration to deliver a substantially more affordable option. For instance, the Trackless Tram carriage effectively starts with a standard light rail carriage that is narrow and has multiple entry doors with a turning radius and grade-climbing ability comparable to a bus, and then provides four new attributes:

1) It harnesses electric drive systems and on-board battery technology to avoid the need for overhead cabling or a fossil fuel engine, with recharge at either stations or end of run areas for longer periods;

2) It substitutes the steel wheels of a train with rubber tyres. This avoids the need for rails and reduces the associated disruption of local economies due to extensive period of construction works on roads and underground services for traditional light rail systems;

3) It provides stabilization technologies through train-type bogeys with low set axles and hydraulic systems designed to prevent sway and bounce; and

4) It adopts autonomous technology through optical guidance systems to provide a precise and smoother ride quality and precision entry to stations and ease of boarding and lighting at platforms by passengers.

Considering the system configuration, the Trackless Tram System uses a dedicated corridor to provide rapid transit services that is supported by fixed stations and a Control Centre, much like light rail or traffic management centres. This provides the benefits in terms of city-shaping provided by traditional light-rail systems. However, the technology provides the flexibility to enable Trackless Trams to be diverted around blockages or quickly recalled should the need arise, unlike an LRT.

\section{The Trackless Tram Transport Niche}

\subsection{Trackless Operation Requirements (Rubber on the Road)}

A Trackless Tram uses rubber wheels that drive on the surface of the road which avoids the need for a substantive part of civil works associated with rail infrastructure. Rubber-tired transit vehicles are a well-established technology. For instance, Michelin patented a steel-belt rubber tire in 1946 which was introduced to regular service on the Paris Metro from 1956. Other cities have developed rubber-tired mass transit systems, including Taipei's Wenhu Line which is an automated rubber-tired train service running on metal plate as part of an elevated track, as shown in Figure 2.

This switch in the design avoids the majority of excavation of the road surface to construct concrete foundations and lay rails, as shown in Figure 3. To ensure 
Table 1. Vehicle specifications for 3-module trackless tram. Source: CRRC Corporation.

\begin{tabular}{cc}
\hline Length & $31.6 \mathrm{~m}$ \\
\hline Width & $2.65 \mathrm{~m}$ \\
Weight (loaded) & 51 tonne (average 9 tonne per axle) \\
Capacity & $250-300$ people \\
Max speed & $70 \mathrm{~km} / \mathrm{hr}$ \\
Gradient & $13 \%$ \\
Turning Radius & $15 \mathrm{~m}$ \\
Design Life & Over 30 years \\
\hline
\end{tabular}

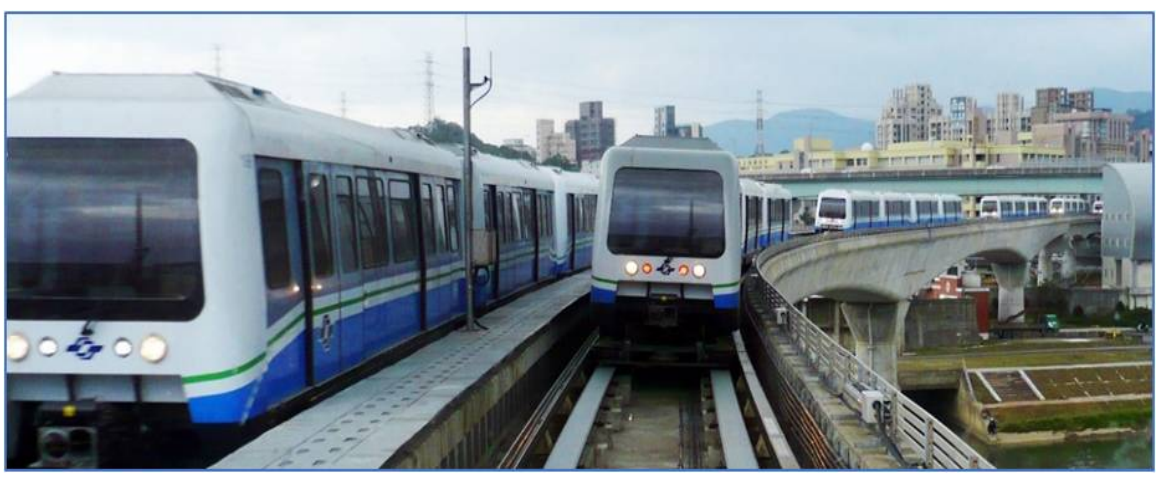

Figure 2. Taipei metro line 1-Wenhu line. Source: Bombardier.

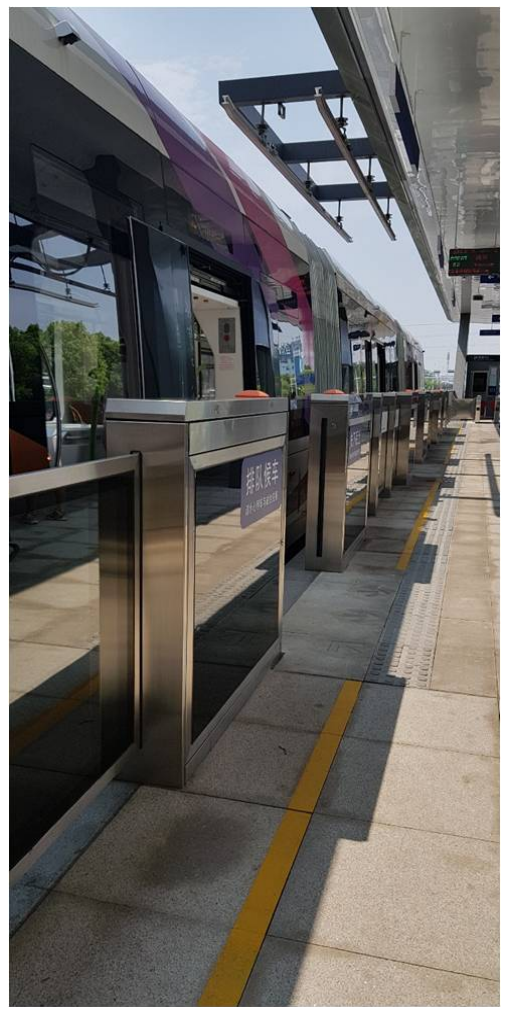

Figure 3. Trackless tram system station. Source: Marie Verschuer. 
a smooth arrival at stations it may be appropriate to construct concrete pads, however the CRRC claim that its light construction means that it can be implemented very rapidly into most urban road systems without change and that after three years of trials there is no sign of road damage.

Implementation is therefore possible to do in a weekend (after all approvals have been gained of course) with modular stations that come as part of the cost of the Trackless Tram System. These contain the desired ticketing and gateway systems as well as recharging facilities for rapid (30 seconds) recharging at stations or longer recharging at the terminus of a route. Implementation can also be simply integrated into a Bus Depot for overnight storage and deep recharge and can use a normal main roads Control Centre to ensure it is running well. The guidance system software and technology to create the exact route can be installed well before the system needs to be running. The best way to enable a mass transit system in a street is to create a free-flowing space and this will require detailed planning but no more or less than with a BRT and probably less than an LRT.

The big difference in implementation of TTS compared with conventional light rail is that a TTS avoids excavation of or interference with buried services such as water mains, electricity cables, telecommunications lines, storm water and waste water systems that add substantially to the cost if disturbed. According to the manufacturer a Trackless Tram vehicle has a loaded weight of $9000 \mathrm{~kg}$ per axle, which is similar to a conventional bus or heavy vehicle but has significantly less pavement impact due to its double axle bogeys, special tyres and the IMU system which manages the sway which causes pavement rutting. Hence pavement construction should not need to be any different for Trackless Trams. There are reasons why the autonomous driving character will minimise road damage as it is not subject to the heavy momentum swings associated with sudden driver interventions. No rutting has been found in the first three years of operation of the Trackless Tram in China (Figure 4).

\subsection{Self-Guiding along "Virtual Rails"}

The Trackless Tram combines a number of autonomous vehicle guidance technologies to follow "virtual rails" along its corridor. The main elements of the guidance system are imaging recognition for optical guidance, satellite navigation, radar point scanning and inertia management. These systems are likely to be used for many autonomous vehicles, especially transit systems that operate in traffic as will be the case in most cities. The lines marked on the road provide optical guidance while also clearly identifying the path of the vehicle for pedestrians and other motorists. Additionally, a differential global positioning system (DGPS) uses fixed positions along the path of the vehicle to constantly update the relative location signals sent and received from satellites-increasing the location accuracy to the order of $10-15 \mathrm{cms}$ from what can be up to $15 \mathrm{~m}$ with traditional GPS. Radar and light point scanning (Lidar) enhances the vehicle's ability to recognize route signs, network characteristics and dynamic interferences 


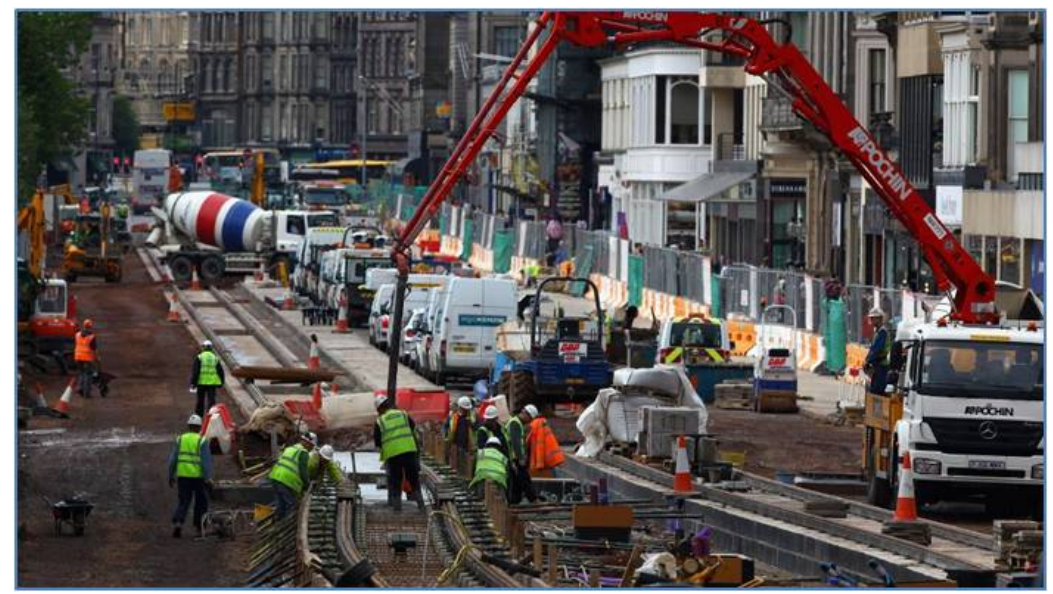

Figure 4. Construction of the Edinburgh tram project. Source: The Independent.

that may occur, fitting this data to the information sourced from the other guidance technologies to create an overall sense of the surrounding environment.

The high precision achieved through the combination of these technologies adds to the appeal of the Trackless Tram by significantly increasing ride quality, improving the safety of the network, and reducing the damage caused to the road surface [10] [11]. In particular, an on-board Inertia Management Unit (IMU) measures the TT's pitch, yaw and roll, adjusting orientation and speed to stabilise the vehicle and create a ride quality characteristic of a rail-based tram or train. Connection to the broader traffic control system through an on-board intelligent transport system (ITS) can control intersection timings and provide real-time feedback to the traffic control centre, driver and passengers. Although it is possible to be driverless the Trackless Tram will have drivers due to its use in mixed traffic where unexpected events can occur and to assist with navigation and assist passengers where needed. Drivers can over-ride the programmed track for the vehicle if there is an accident or blockage.

\subsection{Electrification and Energy Storage}

The Trackless Tram is electric and is powered by on-board lithium ion phosphate batteries (with a 25-year lifespan) that are supplemented by regenerative braking. The form of battery used by CRRC can recharge faster than many other lithium ion batteries and perform better in cold conditions. The $600 \mathrm{~kW}-\mathrm{Hr}$ on-board batteries can quick-charge at $10 \mathrm{kV}$ platform-style overhead charging stations during normal operation, and do 10 minute recharging at the end of a line as well as a deep recharge overnight in a Bus Depot. The CRRC Corporation estimates that for their $3^{\text {rd }}$ generation vehicle a 10-minute charge can provide enough energy for between 15 and $25 \mathrm{~km}$ of travel depending on the loading and the level of air-condition required; with the fourth generation Trackless Tram the battery is anticipated to extend this to $50-60 \mathrm{~km}$. Given the imperative to shift away from fossil fuels, especially diesel causing health impacts in cities, the 
electrification of transit systems provides a way to harness renewable energy generation, especially during daylight hours when solar energy is generated. Along with these improvements an electric drive system offers better ride quality through smoother acceleration/deceleration and less vibrations compared with an internal combustion engine vehicle.

\subsection{Cost Efficiency}

The cost of Trackless Trams can be substantially lower than that of light rail. For instance, in a report commissioned by the City of Parramatta in Sydney, Bodhi Alliance and EDAB Consulting [12] estimated that a Trackless Tram option would have capital costs three times less than a light rail option. The biggest uncertainty in these figures is around construction costs in the road and tracks as well as the needs of particular design requirements around stations [13]. The presence of buried wires and pipes can severely complicate light rail construction. It is highly undesirable to build a light rail line on top of this critical infrastructure, as accessing them may require digging up the line, at huge expense. Such services are generally relocated when a light rail line is built, increasing the capital cost of installing the line. Such costs were found in the recent Sydney Light Rail which has taken nearly four years to complete a $20 \mathrm{~km}$ track through the old part of Sydney at the cost of nearly USD $\$ 130$ million per $\mathrm{km}$ which is around ten times the cost of a Trackless Tram.

Compounding this problem, records are often not able to pinpoint the exact location of services, and in some cases the record of their very existence may have been lost. This creates a major uncertainty in the cost of the infrastructure provision for urban rail-based systems. This uncertainty is a particular problem in older cities, where infrastructure may have been laid down many years ago. While light rail projects typically take years to build, the Trackless Tram can be installed much more quickly (assuming suitable quality roadways and stations being prefabricated for rapid onsite erection). This will reduce the level of disruption to businesses, residents or traffic flows associated with light rail construction, though space must still be found in the roadway.

\subsection{Modal Interoperability: Does the System Allow for First and Last Mile Services?}

The Oxford Dictionary defines "interoperability" in the context of computer systems as a characteristic of a system where the various components are able to work with one another and exchange information despite being of different form, and use the example "interoperability between devices made by different manufacturers" [14]. In a similar way, we use "Modal Interoperability" in the context of transportation systems to describe a system where corridor mass transit and last mile services/modes seamlessly integrate. Given the race to deliver to market a functional and safe driverless vehicle by the world's automakers the technology in this area has seen significant recent research and development. 
Despite it being applied primarily to private vehicles it also stands to assist public transport as Trackless Trams and other rail systems across a city still need first mile/last mile linkages at stations. If these can be electric autonomous shuttles then they need to be serviced at stations and this requires interoperability between the electric recharge systems. The CRRC have designed the Trackless Tram station recharge system to have such interoperability. This approach can see a fleet of $8-12$ person driverless shuttles used as feeder and distributer services around stations (See Figure 5).

The following examples illustrate the fleet size and transit service possible from such a system:

1) Trackless Tram Corridors: Much like light rail systems, Trackless Tram Systems are well suited to corridors of $8-20 \mathrm{~km}$ that serve the inner areas of large cities with stations spaced in the order of $600-1200 \mathrm{~m}$ apart, serving 1.5 $\mathrm{km}$ around each station. For instance, a $20 \mathrm{~km}$ line with 25 stations and three autonomous shuttles per station (carrying up to 12 passengers) that provides a service every 20 minutes would be able to feed around 120 people per hour into the station and service up to 3,000 people per hour along the entire corridor.

2) Low Density Heavy Rail Corridors: Modern heavy rail lines are fast and have high capacity, carrying people along long corridors with stations around 3 to $4 \mathrm{~km}$ apart. A Heavy Rail transit line from the CBD extending out $30 \mathrm{~km}$ with 8 stops would need each station to be serviced by a larger fleet of autonomous shuttles than a Trackless Tram System. To provide a service every 5 minutes each station would have around 6 shuttle loops with 4 shuttles per loop to service a $2.5 \mathrm{~km}$ radius around the station (creating an urban corridor of $150 \mathrm{~km}^{2}$ ). This would require in the order of 192 shuttles for the entire line that would have the potential to deliver nearly 7000 people per hour to the system, in addition to those that walk or cycle, or use a conventional bus to reach their local station. Such lines could also be linked radially around cities by Trackless Tram corridors.

3) Medium Density Heavy Rail Corridors: For higher density corridors like traditional transit fabric from the early $20^{\text {th }}$ century, stations would generally be closer together (traditionally $1.6 \mathrm{~km}$ apart) and would have higher capacity of around 20,000 - 40,000 passengers per track per hour. With stations spaced every $1.5-2 \mathrm{~km}$, smaller catchments per station would allow higher frequency autonomous shuttles (providing a service every 3 minutes), with the capacity to deliver nearly 12,000 passengers per hour to the system. Again, such lines could also be linked radially around cities by Trackless Tram corridors.

4) City Wide Application: Considering a city in the order of 2 million people, and assuming a corridor transit network of 15 heavy rail lines and 20 trackless Tram (TTS) lines this would involve 200 heavy rail stations (each with an average of 20 shuttles) and 500 TTS stops (each with an average of 3 shuttles) - so a fleet of 5500 shuttles would be required to service the entire city. Assuming each shuttle delivers 20 passengers per hour to a station the system could deliver as 

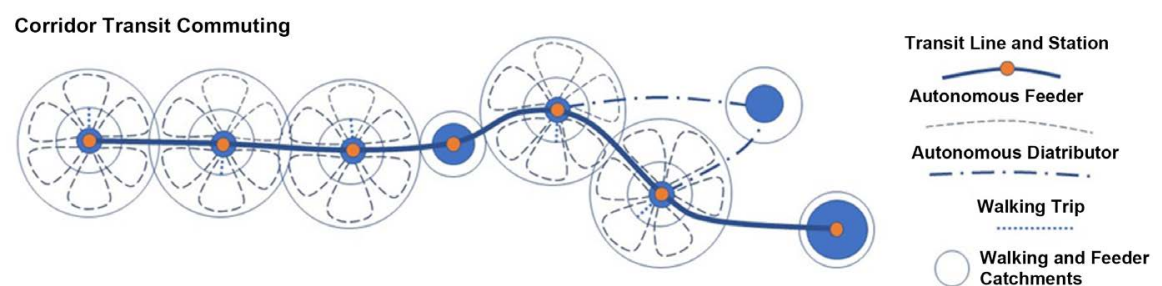

Figure 5. Potential for First and Last mile provision using self-driving shuttles for feeder and distributor services. Source: Amended from Glazebrook and Newman [15].

many as 110,000 passengers per hour on average, or 200,000 during the morning peak period. This would translate to around 1 million extra heavy rail and Trackless Tram trips per day (500,000 in each direction).

According to Metro Report International there are a number of early movers in this autonomous shuttle space such as a trial on the Nanyang Technological University campus in Singapore using a system with "magnetic pellets on the road for navigation and a maximum speed of $40 \mathrm{~km} / \mathrm{h}$ ", as shown in Figure 6 [16].

Other examples include the City of Arlington, Texas, beginning trials on 2017 of the use of self-driving shuttles to provide services between the car parking area and the city's entertainment district during large events. According to the Community Development and Planning Director for the City, John Dugan, “The pilot project will allow us to see how this driverless vehicle system really works and to look at the overall picture of how these vehicles could enhance the city's transportation options." Two self-driving shuttles provided by EasyMile will carry up to 12 passengers at a speed of $30 \mathrm{~km} / \mathrm{hr}$ [17]. Similar trials are underway in the Greenwich Peninsula in southeast London [18], the Seestadt District of Wien in Austria (including the development of legal guidelines) [19], between the stations of Austerlitz and Lyon in Paris using a dedicated road lane [20], Mixed traffic trials are also underway on the CEA Paris-Saclay Research Campus in France [21], the Brussels Airport in Belgium [22], and the city of Neuhausen am Rheinfall in Switzerland [23]. A similar shuttle is being trialled on Curtin University campus and it will be the subject of a future research paper, particularly how it can be integrated into a Trackless Tram corridor.

\subsection{Conclusions of the Trackless Tram Transport Niche}

These factors all suggest that a Trackless Tram System (TTS) is likely to replace Light Rail and Bus Rapid Transit systems due to its ability to mimic all the best qualities of these systems while harnessing technology from High Speed Rail. The Trackless Tram can run rapidly in the road system but not cause the pollution and noise of BRT or the disruption and high construction cost of the LRT. The corridor system can be complimented by an electric shuttle service providing last mile/first mile interoperability as outlined. The significant cost reduction makes it highly attractive to fill the niche currently occupied by BRT and LRT with a TTS. Such a system is likely to provide a major reduction in car and bus 


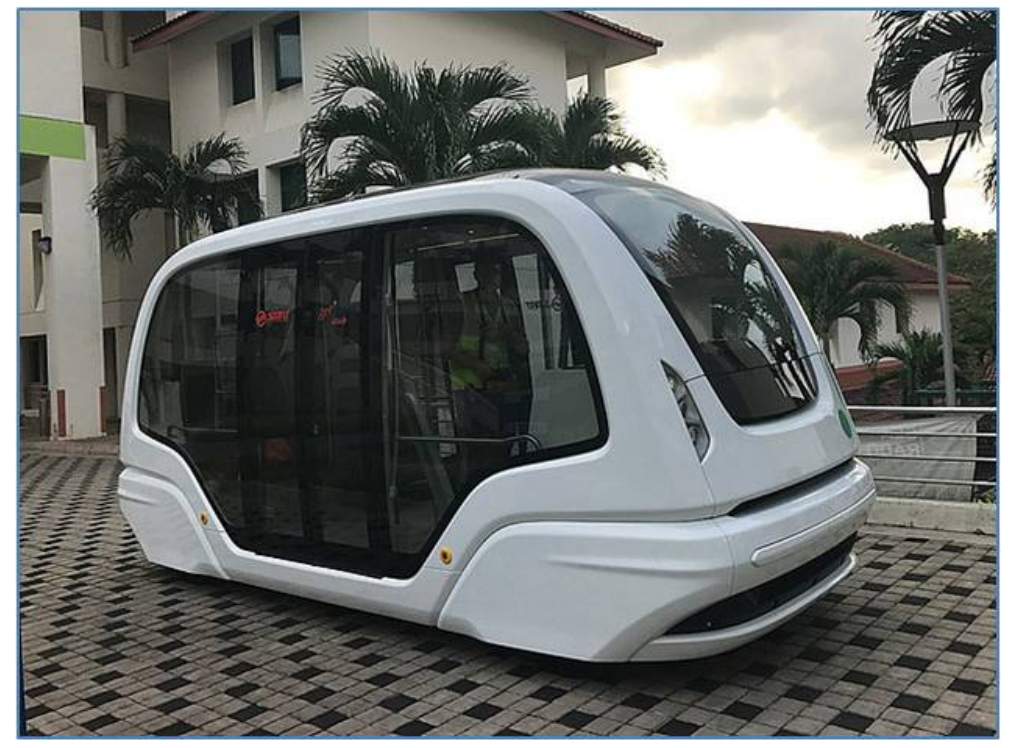

Figure 6. Trial Autonomous Shuttle on Nanyang Technological University campus in Singapore. Source: Metro Report International.

dependence while offering greater accessibility. However, there is one more major attraction of the Trackless Tram System that stands to provide a powerful drive for urban renewal and development. This is the city-shaping potential which is illustrated through two case studies in the following part.

\section{Considering the City Shaping Potential of a Trackless Tram System in Economic, Environmental and Social Terms}

The city shaping potential of a light rail or heavy rail has been well documented [3] and has many economic, social and environmental advantages. The assessment of how a Trackless Tram can help with city shaping is set out below by applying the assessment criteria to two different cities, one a developed city, Perth in Australia and the other Thimphu in Bhutan.

\subsection{Sprawl Relief: Does the System Contribute to Slowing Urban Sprawl?}

Effective and efficient corridor transit allows for a slowing of urban sprawl by facilitating greater urban density. This is demonstrated in the two cities. Firstly, a developed city, Perth, the capital city of Western Australia with a population of 2 million people that has sprawled over $150 \mathrm{~km}$ along the coastline and where various strategies have been proposed to increase redevelopment rather than greenfield sprawl, without success. Secondly a developing city, Thimphu, the capital city of The Kingdom of Bhutan with a population of 100,000 with aspirations to grow to 400,000 in a valley with very limited development space and hence where sprawl management is critical.

Perth has a history of automobile dependence since its strong urban growth period from the 1950's onwards [24]. Like many developed cities it had tram- 
ways from the 1900's to the 1950's but then shifted favour to the car, sprawling $150 \mathrm{kms}$ along the Indian Ocean coastline and creating numerous urban issues. Perth had a rail revival from the late 1980's that has seen its heavy rail system grow from 7 million passengers a year to 70 million [24]. However, the heavy rail system has been implemented in limited corridors and mostly provides services to people in the outer suburbs with destinations towards the city centre. Several attempts have been made to create a light rail system that can service corridors that are currently served only by buses and are dominated by cars, but a feasible model for funding the system has yet to be adopted. Detailed planning led to a system that would cost $\$ 80 \mathrm{~m}$ per $\mathrm{km}$ and would have led to 2 - 3 years of disruption to inner city streets; the system was abandoned in 2016 with a commitment by the State Government to examine potential new ways of doing light rail. Meanwhile a $\$ 6 \mathrm{~b}$ heavy rail system was committed to along new outer area corridors after a proposed unpopular freeway was cancelled and the funding recycled into the rail package. This is likely to make urban sprawl easier and yet the State's plan is to enable more than half of urban development to be focussed back into the inner and middle suburbs. This plan now needs a transit solution that can unlock such re-development potential [25].

Thimphu has seen a rapid rise in automobile use and the subsequent consumption of petroleum fuels with both fully imported into Bhutan. According to the Asian Development Bank [26] it is anticipated that the number of vehicles in Bhutan will rise from 75,000 in 2015 to over 350,000 in 2040. As of August 2018, the latest statistics by the Road Safety and Transport Authority of Bhutan indicated that $52 \%$ of the total vehicles in the country are in the Thimphu region. According to Hargroves and Newman [27] this is likely to cause issues such as increases in road fatalities, air pollution, greenhouse gas emissions, fuel imports, and congestion and will disrupt many of the nation's plans for simultaneously improvements in carbon neutrality, Gross National Happiness and economic growth [28]. Fuel imports place a significant economic toll on Bhutan being nearly equivalent to the entire hydroelectricity revenue generated by the Kingdom. In 2015 Prime Minister Tobgay stated that, "My target for Bhutan is a 70 percent reduction in fossil fuel imports by 2020". Such a goal can only be achieved through greater electrification of transport, with significant hydropower reserves available considering that in 2011 the Asian Development Bank [26] estimated that just 6 percent of the estimated 30,000 MW of hydropower potential in the country was being harnessed.

Considering the potential for slowing urban sprawl in Perth a proposal [29] to develop a new $25 \mathrm{~km}$ transit corridor with 12 stations stands to reduce the need for development on the fringes from $100 \mathrm{~km}^{2}$ to $65.7 \mathrm{~km}^{2}$ of urban re-development-see Table 2. Hendrigan and Newman [30] estimate that some 30 years of urban growth could be accommodated in and around new and revived transit stations if a program of light rail was introduced to complement the new heavy rail and was associated with such station precinct-focussed urban regeneration. 
Table 2. Estimates of land space savings from adoption of corridor transit systems in Perth, Australia and Thimphu, Bhutan.

\begin{tabular}{cccc}
\hline Parameter & Perth & Thimphu & Units \\
\hline Predicted Additional Population & 120,000 & 300,000 & People (Ppl) \\
Population Density (Fringe) & 12 & 40 & Ppl/Hectare \\
Population Density (Corridor Stations) & 35 & 80 & Ppl/Hectare \\
Additional Area Required (Fringe) & 100 & 75 & $\mathrm{~km}^{2}$ \\
Additional Area Required (Corridor Stations) & 34.3 & 37.5 & $\mathrm{~km}^{2}$ \\
Area saved by corridor transit approach & $\mathbf{6 5 . 7}$ & $\mathbf{3 7 . 5}$ & $\mathbf{k m}^{\mathbf{2}}$ \\
\hline
\end{tabular}

Similarly, Thimphu, a city of $26 \mathrm{~km}^{2}$, plans to accommodate population growth from 100,000 to 400,000 people calling for the city to quadruple in size. Given the steep topography of the valley that the city is located in it is not an option to spread this out much beyond the footprint of the present city. It will be crucial for Thimphu to increase urban density in order to accommodate this population increase through urban re-development. As Table 2 shows a proposal by Hargroves and Gaudremeau [31] to develop a new $8.5 \mathrm{Km}$ transit corridor with 12 stations stands to reduce the need for land from $75 \mathrm{~km}^{2}$ on the fringes to $37.5 \mathrm{~km}^{2}$ of urban re-development.

\subsection{Congestion Relief: Does the System Contribute to Alleviating Congestion?}

Traffic congestion is an ongoing issue facing transport planners and network managers with levels of congestion growing to unworkable levels in many of the world's cities, calling for alternative strategies rather than simply seeking to accommodate more automobiles. In 2015 alone Australia's capital cities were estimated to have a combined congestion cost of $\$ 16$ billion, expected to increase to $\$ 37$ billion by 2030 [32]. Perth's congestion costs are expected to increase the most based on anticipated growth from the mid 2010's, almost tripling from $\$ 2$ billion in 2015 to $\$ 5.7$ billion in 2030 [32]. In the US, the cost of congestion in 2012 was estimated to be in the order of $\$ 121$ billion, the equivalent of $\$ 818$ per commuter per year, and some additional 25 million tonnes of $\mathrm{CO}_{2}$ per year [33]. Together with lost time alleviating congestion leads to reduced vehicle wait times in traffic jams which reduces vehicle exhaust, thus reducing carbon emissions and air pollution. In the US alone, 25 million tonnes of $\mathrm{CO}_{2}$ per year was emitted from vehicles delayed on congested roads [34]. In addition, inhaling vehicle exhaust for extended periods has also been linked to human health problems such as brain-cell damage [39].

Newman and Kenworthy [3] show that most cities are now building urban rail instead of accommodating more automobiles as the speed of such transit systems has been increasing in all cities relative to the speed of traffic and bus speeds are simply not competitive even with the declining private vehicle speeds 
as buses are usually stuck in the traffic. The rail option will deliver more lasting congestion relief and is likely to enable emerging cities to break out of their traffic spiral [35]. This is evident when considering that one lane of roadway can carry an average of 2500 people per hour per $\mathrm{km}$ with cars compared to dedicated corridor transit options such as a Trackless Tram System which can carry as much as 20,000 people per hour per $\mathrm{km}$, as shown in Table 3. Where feasible, heavy rail has even greater patronage potential of up to 50,000 people per hour per $\mathrm{km}$. The new Hong Kong East Rail Line is achieving a capacity of 86,000 people per hour per direction during the morning peak; thisis much higher than the average as it is operating 12 rail cars ( 3750 people per train) running every 2.5 minutes due to the use of new autonomous technology such as outlined above in the rail system [36].

Given the issues related to congestion, air pollution, and greenhouse gas emissions it makes sense to take advantage of higher capacity options, especially heavy rail, however connections down corridors using transit such as light rail or Trackless Trams would also be a much better transport option rather than accommodating more automobiles.

\subsection{Reclaim Car Parking: Does the System Allow the Reduction of Car Parking Requirements?}

As outlined above there is a large land requirement associated with urban fringe development and lesser but still significant requirement for land to accommodate urban re-development. If a transport option can be enabled such as the system outlined in section 2.5 above, then there is a large reduction in the need for parking which can save up to a third of the land that then can be available for more productive urban uses. Considering the potential to reclaim car parking space in cities, the International Energy Agency [37] suggests that by 2050 India was on track to require between 10,000 - 20,000 square kilometres of surface parking area, equating to 35 times the size of Mumbai. According to Newman and Kenworthy [38] automobile dependent cities around the world can typically have between 5 and 8 car parking spaces for every car in the city. In Perth for instance there is on average 4 parking spaces per person in inner-city areas, and as much as 10 in outer suburb areas [39]. This means that a significant amount of the land in cities is being allocated to parking vehicles which could be used for higher return development options. Much of this land could be unlocked by integrating a new Trackless Tram line with a series of land developments associated with station locations along the corridor, coupled with quality walking and cycling options, which can enable parking to be reduced to less than one per household. As outlined in section 2.5 the model of the Trackless Tram augmented with local autonomous shuttles can remove any need for station precinct parking.

To put this into context, in the proposed corridor transit project in Perth each of the 12 proposed stations would serve an estimated 10,000 residents who 
Table 3. Estimations of average patronage capacity for various transport modes. Source: Compiled from Newman and Kenworthy [3] [39].

\begin{tabular}{ccc}
\hline Transport Mode & $\begin{array}{c}\text { Average Passengers per hour } \\
\text { per lane per km }\end{array}$ & $\begin{array}{c}\text { Multiples of car capacity in a } \\
\text { suburban street }\end{array}$ \\
\hline Car in suburban street & 1000 & 1 \\
Car in freeway lane & 2500 & 2.5 \\
Bus in traffic & 5000 & 5 \\
Bus in freeway lane (BRT) & 10,000 & 10 \\
Trackless Tram (or Light Rail) & 20,000 & 20 \\
Heavy Rail & 50,000 & 50
\end{tabular}

would require at the very most four parking spaces in the urban area they use rather than ten if they were on the fringe, saving a total of $9.3 \mathrm{~km}^{2}$ (based on minimum parking size requirements of $5.4 \mathrm{~m} \times 2.4 \mathrm{~m}$ ). In Thimphu rather than a 4 inner-city and 10 outer suburb parking allocations as is the case of Perth, it is assumed that there would be a reduced need of 2 inner city and 4 outer suburb car parks per person, with the proposed corridor transit system saving as much as $7.7 \mathrm{~km}^{2}$ of parking space, as shown in Table 4.

\subsection{Job Creation: Does the System Contribute to Job Creation from Greater Urban Density?}

A clear relationship exists between the density of employment and the proportion of new knowledge economy jobs [40]. For over a century urban productivity has been shown to be directly correlated to both the knowledge sharing effects induced by density and human capital cultivated in cities [41] [42] [43] [44]. The proximity of businesses and activity centres within dense urban areas allows for the face-to-face interaction of knowledge-based economy workers and thus enables the flow of knowledge and innovation in any $21^{\text {st }}$ century city. A study by Haughwout [45] suggested that doubling of a country-level density index increases state-level productivity by 6 percent but this is much higher if urban densities are considered. When highly-skilled workers are involved, density also plays an important role in urban innovation [46], with studies showing that the doubling of spatial employment density can increase the intensity of patent creation by 20 percent [47].

According to Kane \& Whitehead [48] agglomeration enables access to a large pool of skilled labour and markets and has the "economies of scale" advantage of bringing the supply of resources, goods and services within easier access. Rawnsley [40] suggests that for firms in higher density areas, they become more competitive as they have access to cheaper and more complementary suppliers, so they can become more specialised and make use of the skilled labour that is much more accessible in denser areas. Even if competing firms are present there may still be benefits such as attracting more suppliers which can compete, and collectively they may attract more customers which can form markets that 
Table 4. Estimates of parking space savings from adoption of corridor transit systems in Perth, Australia and Thimphu, Bhutan.

\begin{tabular}{cccc}
\hline Parameter & Perth & Thimphu & Units \\
\hline Predicted Additional Population & 120,000 & 300,000 & People \\
Car Park Supply (Urban Fringe) & 10 & 4 & Ppl/Hectare \\
Car Park Supply (Corridor Transit) & 4 & 2 & Bays/Hectare \\
Additional Parking Area Required (Fringe) & 15.6 & 15.4 & $\mathrm{~km}^{2}$ \\
Additional Parking Area Required (Corridor) & 6.2 & 7.7 & $\mathrm{~km}^{2}$ \\
Area saved in a corridor transit approach & $\mathbf{9 . 3}$ & 7.7 & $\mathbf{k m}^{2}$ \\
\hline
\end{tabular}

could not have been generated with one firm alone. For individuals, they have access to the opportunities that this rich cluster of productivity and innovation enables.

Newman and Kenworthy [3] point out that corridor transit stations integrated into land development create the conditions of walk ability in densely occupied areas surrounding stations that enable the face-to-face creative discussions for the jobs of the new economy to flourish in other areas of the city as well as central business districts. As densities continue to increase, automobile dependence cannot facilitate the necessary movement of large amounts of people into central areas or into sub centres in the suburbs, hence mass transit is required such as the Trackless Tram System. Graham [49] suggests that workers need to be able to move efficiently between homes and workplaces, and reduced travel times and costs enable greater agglomeration benefits to be realised. As agglomeration is shown to provide increasing returns for cities, investment in transport thus induces positive productivity returns by enabling the development of economic mass [49] [50]. For workers, new opportunities emerge through new innovations, changed ways of working and operating for firms, and new businesses and collaborations emerge within areas of rich networking and interaction. A study by Rawnsley [40] suggests that increasing effective job density by 50 percent can increase labour productivity by as much as 175 percent due to the creation of knowledge economy jobs. A Trackless Tram Systems is thus not just smart technology it is enabling powerful economic development to be unlocked.

\subsection{Environmental Benefits: Does the System Provide Environmental Benefits?}

In addition to car-related environmental impacts, greenfield expansion on the urban fringes is also commonly cited as the cause for loss of farmland, open space, forest and habitat [51]. Figure 7 shows the correlation between urban density and per capita energy use for transport. It is clear that as urban density increases, there is a drastic reduction in energy consumptions per person for passenger transport, resulting in less air pollution and greenhouse gas emissions. 


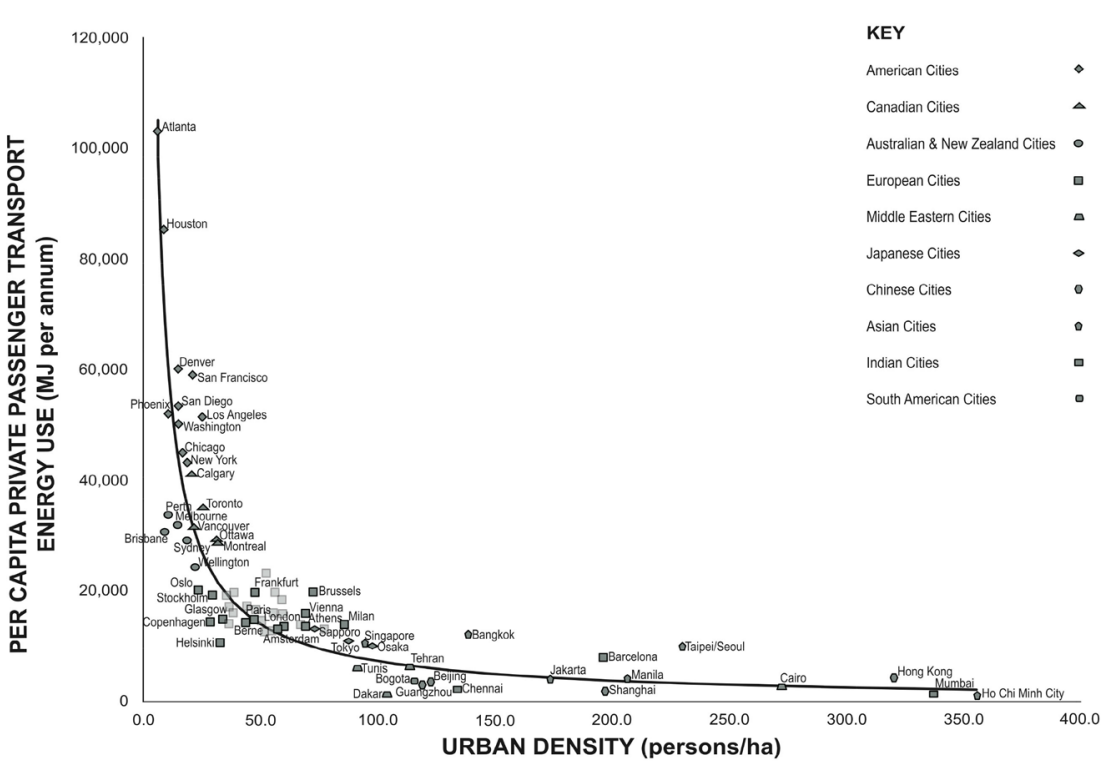

Figure 7. The relationship between urban density and per capita private passenger transport energy use. Source: Newman and Kenworthy [3].

The advent of the Trackless Tram System now makes urban re-development and higher densities to be far more achievable and affordable for cities around the world, especially in the developing world.

With transport constituting approximately 23 percent of global energy-related greenhouse gas emissions [52], viable transport solutions need to reduce fossil fuel consumption, such as systems based on high-density urban areas with effective electric corridor transit solutions, such as the Trackless Tram System. Hence transit systems that provide commuters with effective corridor transit powered by electric vehicles that charge at grid-connected stations which are powered by renewable sources stand to significantly reduce transport-related fossil fuel consumption and associated greenhouse gas emissions. This will be even more effective if local shared mobility autonomous electric shuttles are also part of the Trackless Tram System. Trubka et al. [53] estimate that a rail transit system can reduce daily per capita greenhouse gas emissions for commuters from the fringe of cities by between $8-10 \mathrm{~kg}$ and those in urban areas by as much as $4 \mathrm{~kg}$. This would be reduced to zero by a Trackless Tram System, assuming that it also uses solar energy as its power source for recharging the vehicles. According to the London Department of Transport even if the electricity for the system is sourced from fossil fuels there are still environmental benefits compared to automobile dependent cities using fossil fuels [54].

\subsection{Social Benefits: Does the System Provide Social Benefits?}

The World Health Organisation (WHO) released data in 2016 showing that an estimated 4 in 5 people living in monitored urban areas are exposed to air quality pollution that exceeds recommended levels [55]. The data also showed that in low-and-middle income cities above 100,000 inhabitants, 98 percent do not meet 
the air quality guidelines. In Thimphu for instance, data from the National Environment Commission showed the level of particulate matter (PM10) was 40.5 $\mu \mathrm{g} / \mathrm{m}^{3}$, just over double the WHO Guideline Level of $20 \mu \mathrm{g} / \mathrm{m}$ for the annual average [31] [56]). Diesel and two-stroke engines are one of the most significant contributors to air pollution in urban areas in Asian countries [57]. According to Hargroves and Newman [27], given that some 45 percent of the Bhutanese population are under the age of twenty years old, shifting to a modern clean transit system to provide mobility in the capital city will have long lasting health benefits. These benefits are in addition to the increases to fitness and health of citizens from increased walking and cycling around station precincts, which has been shown to greatly improve the health of populations and can even outweigh the benefits of air pollution reduction [58].

In addition to air pollution benefits a shift to corridor transit will reduce vehicle collisions and road fatalities. According to the WHO more than 1.3 million people die annually on the road in the world and another 20 - 50 million are injured. A study by the WHO and the Asian Development Bank found that Bhutan is second only to Nepal in the number of road deaths per 10,000 vehicles. To compound this social challenge, neighbourhoods of lower-socio-economic status generally tend to have the highest motor vehicle collision rates [59], and can often be more dependent on non-motorised modes to travel longer distances, which can increase the complexity of the system and increase risk for vulnerable road users [60]. On the other hand, studies have shown that public transport is up to ten times safer per mile than private vehicle travel, and that transit-oriented communities are twice as safe [61]. The Trackless Tram has the ability to create such benefits for communities.

The need for cities to engage their citizens and provide equitable solutions for their future has been a major thrust of the New Urban Agenda [62]. This is not just needing social policies by central and local governments that focus on all their communities, but it does have a spatial and urban form dimension. There is now an awareness that pushing affordable housing to the urban fringe does not enable equitable and sustainable living but that a policy of including affordable housing in any new urban re-development is more likely to create the inclusive outcomes sought by the New Urban Agenda [62] [63]. These environmental and social issues have tended to be put aside in the need for cities to achieve competitive economic development, however the Trackless Tram System may indeed be able to solve these at the same time as enabling better economic outcomes.

\subsection{Conclusions of City Shaping Potential of Trackless Tram Systems}

As this paper has shown there are multiple benefits that can be achieved by implementing a Trackless Tram System as the basis of city shaping. The Trackless Tram System is likely to contribute to most of the SDG's especially the need for an "inclusive, safe, resilient and sustainable city" not just because of its technol- 
ogy but because it enables city shaping. The need for urban regeneration to create new centres of urban activity is now a high priority for most cities. The Trackless Tram has all the qualities to enable such densities and mixed urban activity to be attracted to station precincts. These Transit Oriented Developments are not new in concept but are hard to deliver unless made into a whole corridor of urban regeneration. According to Newman et al. [6] this is feasible if a Trackless Tram System is delivered using an entrepreneurial approach that brings private investment into the partnership from the beginning. The approach, together with the very low capital cost of a TTS, means that significant capital burden can be removed from governments who usually are seeking public private partnerships to deliver infrastructure for development but in the past have had to take the major cost for transport, especially transit. The TTS may enable a breakthrough in facilitating partnerships that attract private investment because they enable urban re-development where they can seek a stable return on their investment. This approach is outlined further in other publications [6] [8].

\section{Comparison Summary}

The best way to draw together the character and potential of a Trackless Tram System is to compare it to Light Rail and Bus Rapid Transit systems. Table 5 sets out how BRT, LRT and TTS compare based on six criteria.

Others looking at the characteristics in Table 5 may rate some characteristics higher or lower however it is the conclusion of the authors after extensive investigations, analysed and set out above, that the Trackless Tram System is the preferable option over the BRT or LRT in the corridor connection niche of transport as well as the city shaping niche of urban planning. The TTS in our assessment is better than a BRT due to its ride quality and land development potential (as is LRT), but it is better than LRT because of its much lower cost, its lack of construction disruption and its much better implementation time. It also has a technology "wow factor" that has been lacking in bus-based public transport options. It therefore is likely to replace LRT in cities and provide far more opportunities for creating the much-anticipated transition to more urban regeneration and less car dependence as well as their associated multiple economic, social and environmental benefits.

\section{Conclusion}

The Trackless Tram System is a new kind of transit system that has been generated by crossover innovations from High Speed Rail being applied to a bus. It is neither a Tram nor a Bus though it has the speed/capacity, ride quality and land development potential of a Tram and the cost, lack of disruption and rapid implementation of a Bus. It is therefore a new kind of transit technology that offers radical and transformative opportunities for cities needing connection across suburbs and electric accessibility that unlocks urban regeneration. The Trackless 
Table 5. Indicative comparison of characteristics of corridor based urban rapid transit systems.

\begin{tabular}{|c|c|c|c|}
\hline Characteristic & $\begin{array}{c}\text { Bus Rapid Transit } \\
\text { (BRT) }\end{array}$ & $\begin{array}{c}\text { Light Rail Transit } \\
\text { (LRT) }\end{array}$ & $\begin{array}{c}\text { Trackless Tram System } \\
\text { (TTS) }\end{array}$ \\
\hline Speed and Capacity & $\checkmark$ & $\checkmark \checkmark$ & $\checkmark \checkmark$ \\
\hline Ride Quality & $x$ & $\checkmark \checkmark$ & $\checkmark \checkmark$ \\
\hline $\begin{array}{c}\text { Land Development } \\
\text { Potential }\end{array}$ & $x$ & $\checkmark \checkmark$ & $\checkmark \checkmark$ \\
\hline Cost & $\checkmark$ & $x$ & $\checkmark$ \\
\hline $\begin{array}{l}\text { Disruption during } \\
\text { construction period }\end{array}$ & $\checkmark$ & $x$ & $\checkmark \checkmark$ \\
\hline Implementation Time & $\checkmark$ & $x$ & $\checkmark$ \\
\hline Overall & $\checkmark$ & $\checkmark \checkmark$ & $\checkmark \checkmark \checkmark$ \\
\hline
\end{tabular}

Tram System presents a tangible and affordable opportunity for cities around the world to combat automobile dependence while providing an obvious economic opportunity for harnessing new land development potential. By harnessing technologies applied in various other forms of autonomous and high technology transport, the Trackless Tram System presents a new and unique transit option that can not only incorporate cutting edge technology but deliver significant economic, social and environmental benefits to the worlds' growing cities.

\section{Conflicts of Interest}

The authors declare no conflicts of interest regarding the publication of this paper.

\section{References}

[1] Kim, T.J. (2018) Automated Autonomous Vehicles: Prospects and Impacts on Society. Journal of Transportation Technologies, 8, 137-150. https://doi.org/10.4236/jtts.2018.83008

[2] Newman, P., Beatley, T. and Boyer, H. (2017) Resilient Cities: Overcoming Fossil Fuel Dependence. 2nd Edition, Island Press. https://doi.org/10.5822/978-1-61091-686-8

[3] Newman, P. and Kenworthy, J. (2015) The End of Automobile Dependence: How Cities Are Moving beyond Car Based Planning. Island Press. https://doi.org/10.5822/978-1-61091-613-4

[4] Koglin, T. (2016) High Speed Rail Planning, Policy and Engineering, Vol IV Trends and Advanced Concepts in High Speed Rail. Momentum Press, New York.

[5] Kenworthy, J. and Schiller, P. (2018) An Introduction to Sustainable Transportation: Policy, Planning and Implementation. 2nd Edition, Earthscan from Routledge, New York and Abingdon.

[6] Newman, P., Davies-Slate, S. and Jones, E. (2017) The Entrepreneur Rail Model: Funding urban Rail through Majority Private Investment in Urban Regeneration. Research in Transportation Economics, 67, 19-28.

[7] Davies-Slate, S. and Newman, P. (2018) Partnerships for Private Transit Investment-The History and Practice of Private Transit Infrastructure with a Case Study 
in Perth, Australia. Urban Science, 2, 84-104.

[8] Davies-Slate, S., Conley, D., Newman, P., Hargroves, K., and Mouritz, M. (In Press) Entrepreneurial Financing of Transit Activated Corridors: Reinventing an Entrepreneurial Approach to Transit. Curtin University Sustainability Policy Institute, Curtin University, Australia.

[9] UNDP (2015) Sustainable Development Goal, United Nations Development Program.

[10] AASTHO (1993) Guide for Design of Pavement Structures. American Association of State Highway and Transport Officials, Washington DC.

[11] Gillespie, T.D. (1992) Effect of Heavy-Vehicle Characteristics on Pavement Response and Performance. Report to the National Cooperative Highway Research Program. Transport Research Board, National Research Council, University of Michigan Transport Research Institute.

[12] Bodhi Alliance and EDAB Consulting (2017) Paramatta Road Public Transport Opportunities Study: Transforming Parramatta Road. Consulting Report to Inner West Council and City of Canada Bay, NSW, Australia.

[13] Amended by Authors from Bodhi Alliance and EDAB Consulting (2017) Paramatta Road Public Transport Opportunities Study: Transforming Parramatta Road. Consulting Report to Inner West Council and City of Canada Bay, NSW, Australia.

[14] Oxford English Dictionary (2018).

https://en.oxforddictionaries.com/definition/interoperability

[15] Glazebrook, G. and Newman, P. (2018) The City of the Future. Urban Planning, 3, 1-20. https://doi.org/10.17645/up.v3i2.1247

[16] Metro Report International (2018) NTU Singapore to Test GRT Autonomous Vehicles.

https://www.metro-report.com/news/single-view/view/ntu-singapore-to-test-auton omous-vehicles.html

[17] Metro Report International (2017) Arlington to Trial Driverless Shuttles. https://www.metro-report.com/news/single-view/view/arlington-to-trial-driverlessshuttles.html

[18] Metro Report International (2017) Driverless Shuttle on Test in London. https://www.metro-report.com/news/single-view/view/driverless-shuttle-on-test-inlondon.html

[19] Metro Report International (2017) Wien to Test Driverless Shuttle. https://www.metro-report.com/news/single-view/view/wien-to-test-driverless-shutt le.html

[20] Metro Report International (2017) Driverless Shuttles Link Paris Stations. https://www.metro-report.com/news/single-view/view/driverless-shuttles-link-paris -stations.html

[21] Metro Report International (2018) Driverless Shuttles on Test in Mixed Traffic in Paris.

https://www.metro-report.com/news/single-view/view/driverless-shuttles-on-test-in -mixed-traffic-in-paris.html

[22] Metro Report International (2018) Brussels Airport to Test Self-Driving Bus in Mixed Traffic.

https://www.metro-report.com/news/single-view/view/brussels-airport-to-test-selfdriving-bus-in-mixed-traffic.html

[23] Metro Report International (2018) Driverless Shuttle Enters Passenger Service in 
Mixed Traffic.

https://www.metro-report.com/news/single-view/view/driverless-shuttle-enters-pas senger-service-in-mixed-traffic.html

[24] Newman, P. (2017) Infrastructure Planning in Perth: Past, Present and Future. In: Biermann, S., Olaru, D. and Paul, V., Eds., Planning Boomtown and Beyond, UWA Press, Perth.

[25] Gaynor, A., Newman, P. and Jennings, P. (2017) Never Again: Reflections on Environmental Responsibility after Roe 8. UWA Scholar Press, Perth.

[26] ADB (2011) Bhutan Transport 2040: Integrated Strategic Vision-Strategies Report. Development Partnership Program for South Asia, Asian Development Bank.

[27] Hargroves, K. and Newman, P. (2018) Considering the Future of Transport in the Kingdom of Bhutan. In: Wismans, J. and Thynell, M., Eds., Environmentally Sustainable Transport (EST) Sourcebook, United Nations Centre for Regional Development.

[28] Yangka, D. and Newman, P. (2018) Bhutan: Can the $1.5^{\circ} \mathrm{C}$ Agenda Be Integrated with Growth in Wealth and Happiness? Urban Planning, 3, 94-112.

https://doi.org/10.17645/up.v3i2.1250

[29] Newman, P., Mouritz, M., Davies-Slate, S., Jones, E., Hargroves, K., Sharma, R. and Adams, D. (2018) Delivering Integrated Transit, Land Development and Finance. A Report to the Sustainable Built Environment National Research Centre (SBEnrc), Curtin University Sustainability Policy Institute, Perth.

[30] Hendrigan, C. and Newman, P. (2017) Dense, Mixed-Use, Walkable Urban Precinct to Support Sustainable Transport or Vice Versa? A Model for Consideration from Perth, Western Australia. International Journal of Sustainable Transportation, 11, 11-19. https://doi.org/10.1080/15568318.2015.1106225

[31] Hargroves, K. and Gaudremeau, J. (2017) Pre-Feasibility Study to Investigate Potential Mass Transit Options for Bhutan. A Report to the United Nations Centre for Regional Development (UNCRD), Tokyo.

[32] BITRE (2015) Traffic and Congestion Cost Trends for Australian Capital Cities. Bureau of Infrastructure, Transport and Regional Economics, Commonwealth of Australia, Canberra.

[33] Mullich, J. (2013) Drivers Avoid Traffic Jams with Big Data and Analytics. Bloomberg L.P., New York.

[34] Hotz, R. (2011) The Hidden Toll of Traffic Jams. The Wall Street Journal.

[35] Gao, Y. and Newman, P. (2018) Beijing's Peak Car Transition: Hope for Emerging Cities in the $1.5^{\circ} \mathrm{C}$ Agenda. Urban Planning, 3, 82-93.

https://doi.org/10.17645/up.v3i2.1246

[36] MTR (2018) Rail Operations: A Service of World Class Quality. https://www.mtr.com.hk/en/corporate/operations/detail_worldclass.html

[37] IEA (2013) Global Land Transport Infrastructure Requirements: Estimating Road and Railway Infrastructure Capacity and Costs to 2050. International Energy Agency Information Paper, IEA.

[38] Newman, P. and Kenworthy, J. (1999) Sustainability and Cities: Overcoming Automobile Dependence. Island Press.

[39] Newman, P. and Kenworthy, J. (1989) Cities and Automobile Dependence: An International Sourcebook, Gower, Aldershot, UK.

[40] Rawnsley, T. (2014) Walking to Global Competitiveness: A Case Study of Melbourne's CBD. Sydney Walk 21 Presentation. 
https://www.sgsep.com.au/publications/walking-global-competitiveness-case-studymelbournes-cbd

[41] Marshall, A. (1890) Principles of Economic. Macmillan, London.

[42] Jacobs, J. (1969) The Economy of Cities. Random House, New York.

[43] Glaeser, E. (1999) Learning in Cities. Journal of Urban Economics, 46, 254-277.

[44] Abel, J., Dey, I. and Gabe, T. (2012) Productivity and the Density of Human Capital. Journal of Regional Science, 52, 562-586. https://doi.org/10.1111/j.1467-9787.2011.00742.x

[45] Haughwout, A. (2000) The Paradox of Infrastructure Investment: Can a Productive Good Reduce Productivity? The Brookings Institute, Washington DC.

[46] Knudsen, B., Florida, R., Stolarick, K. and Gates, G. (2008) Density and Creativity in U.S. Regions. Annals of the Association of American Geographers, 98, 461-478. https://doi.org/10.1080/00045600701851150

[47] Carlino, G., Chatterjee, S. and Hunt, R. (2007) Urban Density and the Rate of Invention. Journal of Urban Economics, 61, 389-419. https://doi.org/10.1016/j.jue.2006.08.003

[48] Kane, M. and Whitehead, J. (2018) How to Ride Transport Disruption-A Sustainable Framework for Future Urban Mobility. Australian Planner, 54, 177-185.

[49] Graham, D. (2007) Agglomeration Economies and Transport Investment. International Transport Forum, Discussion Paper No. 2007-11.

[50] Venables, A. (2007) Evaluating Urban Transport Improvements: Cost-Benefit Analysis in the Presence of Agglomeration and Income Taxation. Journal of Transport Economics and Policy, 41, 173-188.

[51] Wilson, B. and Chakraborty, A. (2013) The Environmental Impacts of Sprawl: Emergent Themes from the Past Decade of Planning Research. Sustainability, 5, 3302-3327. https://doi.org/10.3390/su5083302

[52] IEA (2017) Tracking Clean Energy Progress 2017. International Energy Agency.

[53] Trubka, R., Newman, P. and Bilsborough, D. (2010) The Costs of Urban SprawlInfrastructure and Transportation. Environment Design Guide, Gen 83, April 2010.

[54] DOT (2007) Delivering a Sustainable Railway. White Paper, Department of Transport, London.

[55] WHO (2016) WHO Global Urban Ambient Air Pollution Database. World Health Organisation.

[56] IISD (2013) Summary of the Seventh Regional Environmentally Sustainable Transport (EST) Forum in Asia. International Institute for Sustainable Development, Volume 210, Number 1, Sunday, 28 April 2013.

[57] Haq, G. and Schwela, D. (2008) Urban Air Pollution in Asia. Stockholm Environment Institute.

[58] Woodcock, J., Edwards, P., Tonne, C., Armstrong, B.G., Ashiru, O., et al. (2009) Public Health Benefits of Strategies to Reduce Greenhouse-Gas Emissions: Urban Land Transport. The Lancet, 374, 1930-1943. https://doi.org/10.1016/S0140-6736(09)61714-1

[59] Abdalla, I.M., Raeside, R., Barker, D. and Scottish Office Central Research Unit (1996) Linking Road Traffic Accident Statistics to Census Data in Lothian.

[60] Rodríguez, et al. (2006) Can New Urbanism Encourage Physical Activity? Comparing New Urbanist Neighborhoods with Conventional Suburbs. Journal of the American Planning Association, 72, 43-54. https://doi.org/10.1080/01944360608976723 
[61] American Public Transport Association (APTA) (2016) Report: The Hidden Traffic Safety Solution: Public Transportation.

[62] United Nations Conference on Housing and Sustainable Urban Development (Habitat III) (2017) New Urban Agenda. United Nations, New York.

[63] Wiktorowicz, J., Babaeff, T., Breadsell, J., Byrne, J., Eggleston, J. and Newman, P. (2018) WGV: An Australian Urban Precinct Case Study to Demonstrate the $1.5^{\circ} \mathrm{C}$ Agenda Including Multiple SDGs. Urban Planning, 3, 64-81.

https://doi.org/10.17645/up.v3i2.1245 